\title{
A CALENDAR OF THE SOCIETY'S ACTIVITIES
}

MAY

1 - Mail Membership Directory (includes MRS Constitution, By Laws, Officers and Committees)

15 - Nominations for the Von Hippel Award must be in the hands of K. N. Tu, Awards Committee President.

JUNE

7-10 - Berlin Meeting, "Scientific Basis for Nuclear Waste Management"

15 - Deadline for submission of abstracts to Symposia Chairpersons

15 - Nominating Committee submits candidates for 1 st and 2nd Vice Presidents, Secretary, Treasurer and five Councillors on ballots to Council (return deadline July 15).

15 - Secretariat tallies ballots for the Von Hippel Award and reports results to Council

\section{JULY}

1 - Deadline for submission of final programs for symposia to Program Committee

15 - Program Committee submits final Program and Registration booklet copy to Secretariat

15 - Secretariat tallies ballots of Council and using this slate of candidates for officers and councillors prepares ballot for distribution to general membership in August

\section{AUGUST}

15 - Deadline for Submission of Final Abstracts by the Symposia Chairpersons to the
Secretariat

15 - Secretariat mails ballots for election of officers and councillors to general membership (return deadline Sept. 15)

31 - MRS mails Preliminary Program with hotel and meeting registration forms

\section{SEPTEMBER}

15 - Final Program and Abstracts submitted to printer

15 - Secretariat reports results of balloting for officers and councillors to Council and notifies candidates of results

23 - Program Committee Meeting with $1982 \quad$ Symposia Chairpersons at Park Plaza Hotel, Boston

\section{OCTOBER}

1 - Awards Committee announces Student Awards Prints inserts with these announcements and those for Von Hippel Award for inclusion in the registration folder (deadline Oct. 29 at hotel)

8 - Announcement by President of $1983 \quad$ Committee Chairpersons to Council and committees of Society ('83 Committee Chairpersons will provide nominations for their respective committees to President before Oct. 25)

25 - Deadline for initial submission to President of nominations for committee members by ' 83 Committee Chairpersons

31 - Society Publications (Proceedings, etc.) with order forms are displayed
31 - (5:30 p.m.) Boston Meeting registration opens

31 - (8:30 p.m.) Committee meetings (open to membership)

1. Publications (C. White)

2. Education (R. Roy)

3. Membership Giessen)

4. Long Range Planning (K. Tu)

31 - (late) Poster boards set up at The Castle

\section{NOVEMBER}

1-4 - Boston Meeting - Boston Park Plaza Hotel

1 - Plenary Session (5:30 - 7:00 p.m.)

2 - Von Hippel Award/Wine and Cheese Reception

\section{MRS BULLETIN}

VOLUME VII

NUMBER 2

The Materials Research Society Bulletin is published bi-monthly by the Materials Research Society for its members and others interested in materials science. Correspondence and submissions are invited. They should be brief and typewritten (double spaced), and the author's affiliation must be indicated. Address technical materials to the Managing Editor and all other materials to the Editor.

H. J. LEAMY

Managing Editor, MRS Bulletin

Bell Laboratories

Murray Hill, New Jersey 07974

T. G. MIDDLETON

Editor, MRS Bulletin

Box 1334

Summit, New Jersey 07901 